\title{
Solubility of $\mathrm{BaSO}_{4}$ Powders in Water Containing a Strong Acidic Ion Exchange Resin
}

\author{
Tadashi SAKURAI, Masayuki NAGAI and Tadashi NISHINO \\ (Laboratory of Inorganic Material, Musashi Institute of Technology) \\ 1-28, Tamazutsumi, Setagaya-ku, Tokyo 158
}

強酸性イオン交換樹脂を含む眯濁水中への $\mathrm{BaSO}_{4}$ 粉体の溶解性

桜 井正・永井 正幸・西野 忠
(武蔵工業大学 無機化学研究室)

\begin{abstract}
In our previous study, it was found that $\mathrm{BaSO}_{4}$ powders, a sparingly soluble salt, was able to dissolve in water suspended with a strong acidic ion exchange resin (abbreviated as $H-R$ ). This paper presents a method to elucidate the surface activity of BaSO, powders which are heat-treated up to $800^{\circ} \mathrm{C}$. Some factors responsible for the dissolution tendency of $\mathrm{BaSO} \mathrm{S}_{4}$ such as $\mathrm{H}-\mathrm{R} / \mathrm{H}_{2} \mathrm{O}$ ratio, soaking temperature and the amount of $H-R$ were examined to determine the optimum condition. The average particle diameter was compared with an electron microscope. A remarkable change in solubility was observed for the $\mathrm{BaSO}_{4}$ powders calcined at $450^{\circ}-500^{\circ} \mathrm{C}$ without any significant change in particle size. Calcination at higher temperatures resulted in a slight increase in solubility in spite of the enhanced grain growth.

[Received February 18, 1986]
\end{abstract}

Key-words : Ion exchange resin, $\mathrm{BaSO}_{\boldsymbol{4}}$, Activity, Solubility

\section{Introduction}

It is generally known that activity of powders depends on many factors such as particle size, shape, size distribution, lattice distortion and imperfections. These factors more or less dominate chemical and physical phenomena in relation to powders, including decomposition, vaporization, sintering, reactivity with other substances, peptization and so $\mathrm{on}^{1 /-3)}$.

Therefore, it is of great importance to estimate activity of powders by a reliable method in order to handle or utilize powders effectively.

Up to the present time, the proposed methods include estimation through specific surface area, catalytic activity, lattice distortion and solubility, among which measurement of solubility is considered one of the most simple and practical method. It is easy to examine the relationship between solubility and activity for inorganic powders with an adequate solubility while it is usually difficult to collect reliable data on sparingly soluble ones.

The authors have found that $\mathrm{BaSO}_{4}$ powders with poor solubility could be dissolved readily into water in the presence of $\mathrm{H}$-form ion exchange resin (H-R) when we tried to determine the exact composition of $\delta-\mathrm{BaCO}_{3}{ }^{4}$. This technique can be applied to estimate activity of sparingly soluble powders by means of solubility measurement. This dissolution procedure is more favorable than that using mineral acids because it can reduce chance of contamination. Consequently, this method may be utilized for chemical analysis of solids with poor solubility. For example, $200 \mathrm{mg}$ $\mathrm{CaSO}_{4}$ powders or $100 \mathrm{mg} \mathrm{SrSO}_{4}$ powders can be easily dissolved in $20 \mathrm{ml} \mathrm{H}_{2} \mathrm{O}$ dispersed with $2 \mathrm{~g}$ H-R.

This study is concerned with an estimation of activity of calcined $\mathrm{BaSO}_{4}$ powders, which is reported to exhibit solubility as low as $10 \times 10^{-6}$ $\mathrm{mol} \cdot \mathrm{dm}^{-3}$ at $25^{\circ} \mathrm{C}^{5}$. After fundamental experiment was conducted to obtain more reliable data, the solubility of $\mathrm{BaSO}_{4}$ powders in the presence of $\mathrm{H}-\mathrm{R}$ as a function of calcination temperature was determined and employed as a simple indication to estimate activity of $\mathrm{BaSO}_{4}$ powders.

\section{Experimental procedure}

Solubility measurement was carried out for about $100 \mathrm{mg} \mathrm{BaSO}$. powders (Merck Co., Ltd.) with diameter ranging from 0.1 to $0.3 \mu \mathrm{m}$ after they were dried at $110^{\circ} \mathrm{C}$ for 2 or 3 days. Before H-R (Dow Chemical Co., Ltd., Dowex $50 \mathrm{~W}$ $\mathrm{X} 4,200-400$ mesh) was used for dissolution, it was washed repeatedly with distilled water. The amount of released $\mathrm{SO}_{4}^{2-}$ caused by cation ex- 
change between $\mathrm{H}^{+}$and $\mathrm{Ba}^{2+}$ was determined with a calibration curve in the concentration range from 5 to $30 \mathrm{ppm}$ using $\mathrm{K}_{2} \mathrm{SO}_{4}$ (Merck Co., Ltd. ) solution as a standard.

The ion chromatography (Dionex Co., Ltd., Ion Chromatography 10) equipped with an anion fiber suppressor at the suppressor column, was operated in the sensitive range of $30 \mu \mathrm{S}$ using a mixture of $3 \mathrm{mM} \mathrm{NaHCO}$ and $2.4 \mathrm{mM} \mathrm{Na}_{2} \mathrm{CO}_{3}$ as an eluent and $0.025 \mathrm{~N} \mathrm{H}_{2} \mathrm{SO}_{4}$ as a regeneration agent. The electrical conductivity and $\mathrm{pH}$ were measured with an electrical conductivity meter (Toa Electronic Co., Ltd., CM-5 B, cell constant 1.03) and a $\mathrm{pH}$ meter (Toa Electronic Co., Ltd., IM-78), respectively, using ultra pure water (Organo Co., Ltd.) as a solvent.

The morphology of the $\mathrm{BaSO}_{4}$ powders was examined by scanning electron microscopy (SEM ; JEOL Co., Ltd., JCXA-733) and transmission electron microscopy (TEM ; JEOL Co., Ltd., JEM-1200 EX).

After overlapping of the particles in the TEM image was eliminated, the average particle size was calculated from the number and area of the particles in the modified TEM image, which were determined with an image analyzer (Nihon Regulator Co., Ltd., LUZEX 500). In this procedure, it is assumed that the presumed particles would be spherical and possess the same area as the actual ones.

\section{Results and discussion \\ 3.1 Dissolution of $\mathrm{BaSO}_{4}$ powders in the presence of $\mathrm{H}-\mathrm{R}$}

3.1.1 Effect of $\mathrm{H}-\mathrm{R}$ on solubility of $\mathrm{BaSO}_{4}$ powders

Although solubility of $\mathrm{BaSO}_{4}$ in $\mathrm{H}_{2} \mathrm{O}$ is negligibly small, it can be increased drastically by the presence of $\mathrm{H}-\mathrm{R}^{4)}$. Figure 1 shows a comparison of solubility for $100 \mathrm{mg} \mathrm{BaSO}_{4}$ powders soaked in $20 \mathrm{ml} \mathrm{H}_{2} \mathrm{O}$ (A), where $3 \mathrm{ml}$ of $1 \mathrm{~N}$ $\mathrm{HCl}$ (B), $1.0 \mathrm{~g} \mathrm{H}-\mathrm{R}(\mathrm{C})$ and $3.0 \mathrm{~g} \mathrm{H}-\mathrm{R}$ (D) were added, respectively.

The amount of dissolved $\mathrm{SO}_{4}^{2-}$ was as small as $0.5 \mathrm{mg}$ for $\mathrm{H}_{2} \mathrm{O}$ and slightly increased to $1.9 \mathrm{mg}$ by adding $\mathrm{HCl}(\mathrm{B})$, while it was remarkably increased with the mass of H-R up to $19.4 \mathrm{mg}(\mathrm{C})$ and $28.5 \mathrm{mg}$ (D). The significant difference indicates that the solubility of $\mathrm{BaSO}_{4}$ can be increased by the presence of H-R. The mechanism of promoted dissolution is thought to be

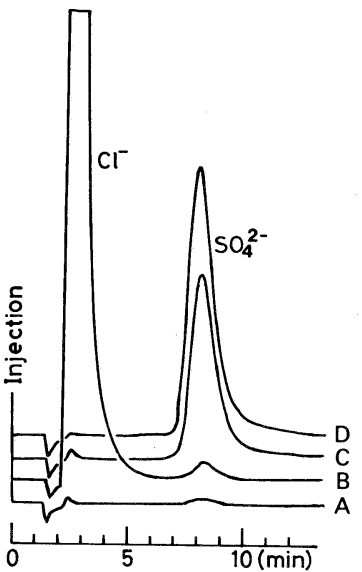

Fig. 1. Ion chromatograms indicating the effect of $\mathrm{H}$ $\mathrm{R}$ on the dissolution of $\mathrm{BaSO}_{4}$ powders in $\mathrm{H}_{2} \mathrm{O}$.

A ; $100 \mathrm{mg} \mathrm{BaSO}_{4}+20 \mathrm{ml} \mathrm{H}_{2} \mathrm{O}$

B ; $100 \mathrm{mg} \mathrm{BaSO}+20 \mathrm{ml} \mathrm{H}_{2} \mathrm{O}+3 \mathrm{ml}_{4} \mathrm{~N} \mathrm{HCl}$

C ; $100 \mathrm{mg} \mathrm{BaSO}_{4}+20 \mathrm{ml} \mathrm{H}{ }_{2} \mathrm{O}+1 \mathrm{~g} \mathrm{H}-\mathrm{R}$

D ; $100 \mathrm{mg} \mathrm{BaSO}_{4}+20 \mathrm{ml} \mathrm{H} \mathrm{H}_{2} \mathrm{O}+3 \mathrm{~g} \mathrm{H}-\mathrm{R}$

much different from the general dissolution mechanism of soluble materials and explained as follows.

The dissolution equilibrium of $\mathrm{BaSO}_{4}$ at a constant temperature is given by the reaction ( 1 ).

$$
\mathrm{BaSO}_{4} \leftrightarrows \mathrm{Ba}^{2+}+\mathrm{SO}_{4}^{2-}
$$

If $\mathrm{H}-\mathrm{R}$ is added to this system, the ion exchange reaction will take place, which is given by the reaction $(2)$,

$$
\begin{aligned}
& \mathrm{Ba}^{2+}+\mathrm{SO}_{4}^{2-}+2(\mathrm{H}-\mathrm{R}) \\
& \quad \longrightarrow 2 \mathrm{H}^{+}+\mathrm{SO}_{4}^{2-}+\mathrm{Ba}_{-} \mathrm{R}_{2}
\end{aligned}
$$

leading to increase in solubility of $\mathrm{BaSO}_{4}$ in which $\mathrm{Ba}-\mathrm{R}_{2}$ denotes exchanged product on the resin.

The ion exchange capacity of $\mathrm{H}-\mathrm{R}$ for $\mathrm{Ba}^{2+}$ has been reported to be about $30 \mathrm{mg}$ per $1 \mathrm{~g} \mathrm{H}$ $\mathrm{R}^{4)}$.

\subsubsection{Effect of dispersion concentration of}

\section{$\mathrm{H}-\mathrm{R}$ on solubility}

$100 \mathrm{mg} \mathrm{BaSO}_{4}$ powders and $4.0 \mathrm{~g} \mathrm{H}-\mathrm{R}$ were added to graded amounts of $\mathrm{H}_{2} \mathrm{O}$ ranging from 20 to $200 \mathrm{ml}$. After the suspensions were kept for $10 \mathrm{~min}$, they were filtered without any washing, and analyzed. As shown in Fig. 2, the solubility tends to decrease with the amounts of coexisted $\mathrm{H}_{2} \mathrm{O}$ contrary to the general dissolution trend of ionic crystal powders.

The dependence of the solubility on dispersion concentration of $\mathrm{H}-\mathrm{R}$ indicates that the solubility is controlled by transportation process of $\mathrm{Ba}$ ion toward the surface of $\mathrm{H}-\mathrm{R}$. 


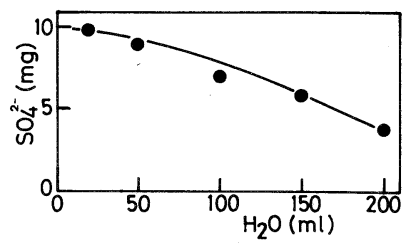

Fig. 2. Solubility of $\mathrm{BaSO}_{4}$ vs. amount of $\mathrm{H}_{2} \mathrm{O}$ in a suspension with $4 \mathrm{~g} \mathrm{H}-\mathrm{R}$.

In order to dissolve $\mathrm{BaSO}_{4}$ effectively, a suspension of $\mathrm{H}-\mathrm{R}$ with small amount of water is favorable to increase the interaction between $\mathrm{Ba}^{2+}$ and H-R.

\subsubsection{Effect of temperature on solubility}

A series of suspensions containing $50 \mathrm{ml} \mathrm{H}_{2} \mathrm{O}$ and $1.0 \mathrm{~g} \mathrm{H}-\mathrm{R}$ were kept at a fixed temperature ranging from room temperature to $80^{\circ} \mathrm{C}$, then, $100 \mathrm{mg} \mathrm{BaSO}_{4}$ powders were added and stirred for $3 \mathrm{~min}$. Immediately after stirring, the suspensions were filtered and cooled down to room temperature and the solubility was determined for each filtrate. As shown in Fig. 3, the amount of dissolved $\mathrm{SO}_{4}^{2-}$ increases monotonously with an increase of soaking temperature. The tendency is some orders of magnitude more than the solubility of $\mathrm{BaSO}_{4}$ in $\mathrm{H}_{2} \mathrm{O}$ viz. $0.22 \times 10^{-3}$ and $0.39 \times 10^{-3} \mathrm{~g} / 100 \mathrm{~g}-\mathrm{H}_{2} \mathrm{O}$ at $25^{\circ}$ and $100^{\circ} \mathrm{C}$, respectively ${ }^{6)}$.

The result suggests that the mobility of $\mathrm{Ba}^{2+}$ in $\mathrm{H}_{2} \mathrm{O}$ is accelerated with temperature.

\subsubsection{Effect of $\mathrm{H}_{2} \mathrm{O}$ amount during filtration} on solubility

As to the dissolution procedure described in 3.1.1 and 3.1.2, no washing of undissolved $\mathrm{BaSO}_{4}$ and $\mathrm{H}-\mathrm{R}$ during filtration was carried out.

However, washing is usually essential procedure for filtration. If $\mathrm{H}-\mathrm{R}$ coexist with $\mathrm{BaSO}_{4}$ powders during washing, it is expected that the cation exchange reaction follows the onset of the dissolution of $\mathrm{BaSO}_{4}$.

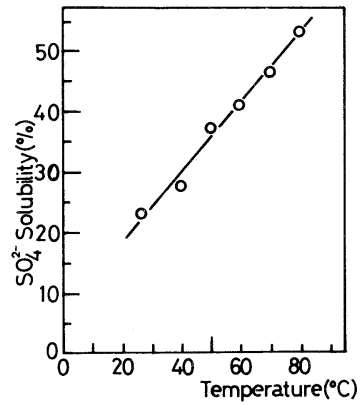

Fig. 3. Dependence of solubility of $\mathrm{BaSO}_{4}$ on the soaking temperature.
Therefore, the dependence of the amount of dissolved $\mathrm{BaSO}_{4}$ on washing was examined. After $20 \mathrm{ml} \mathrm{H}_{2} \mathrm{O}$ and $100 \mathrm{mg} \mathrm{BaSO}_{4}$ powders were added to $4.0 \mathrm{~g} \mathrm{H}-\mathrm{R}$, the solutions were stirred for $5 \mathrm{~min}$ and filtered.

The resultant residue was washed with $\mathrm{H}_{2} \mathrm{O}$, the amount of which ranged from 40 to $300 \mathrm{ml}$, subsequently the summation of dissolved $\mathrm{SO}_{4}^{2-}$ in the filtrate and washings was determined. The relationship between these two amounts is shown in Fig. 4. The dissolved amount of $\mathrm{SO}_{4}^{2-}$ increases nearly in proportion with the amount of washings, indicating that dissolution of $\mathrm{BaSO}_{4}$ can take place during washing of the residue.

Therefore, it is essential to compare the dissolution data in the presence of $\mathrm{H}-\mathrm{R}$ under the condition that the solutions are filtered without washing or that they are filtered with a constant amount of washing.

\subsubsection{Dissolution behavior of $\mathrm{BaSO}_{4}$ with the} amount of $\mathrm{H}-\mathrm{R}$

The solubility of $\mathrm{BaSO}_{4}, \mathrm{pH}$ and electrical conductivity were measured for the suspension prepared as follows. After $100 \mathrm{mg} \mathrm{BaSO}$, was put into $50 \mathrm{ml} \mathrm{H}_{2} \mathrm{O}$ and $\mathrm{H}-\mathrm{R}$, the amount of which ranged from 0.5 to $10.0 \mathrm{~g}$, was added to the

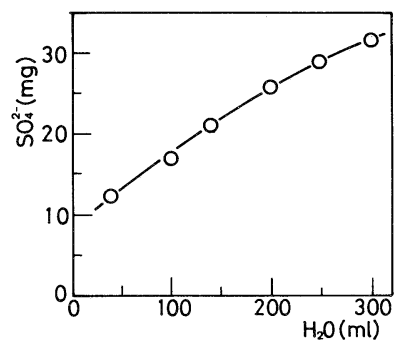

Fig. 4. Effect of washings on the dissolution of $\mathrm{BaSO}_{4}$.

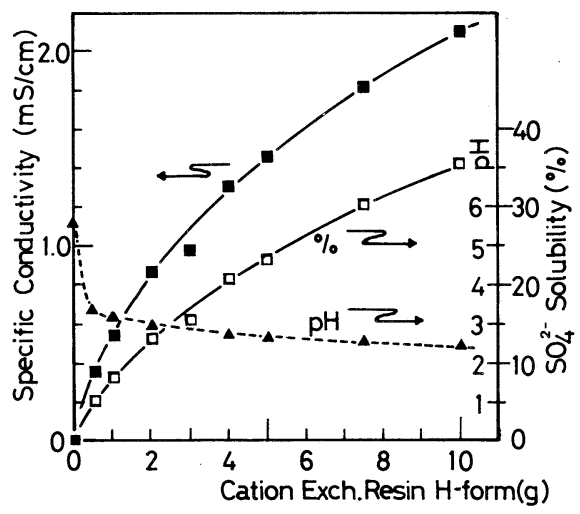

Fig.5. Dissolution behavior of $\mathrm{BaSO}_{4}$ with the amount of $\mathrm{H}-\mathrm{R}$. 
resultant suspension, it was kept for $10 \mathrm{~min}$, filtered without washing and analyzed. The solubility, $\mathrm{pH}$ and the specific conductivity as a function of the $\mathrm{H}-\mathrm{R}$ amount are shown in Fig. 5.

With an increase in the H-R amount, the solubility and the conductivity increased whereas the $\mathrm{pH}$ decreased. Analogous results were obtained for anhydrous $\mathrm{CaSO}_{4}$ and $\mathrm{SrSO}_{4}$ powders. Furthermore, the specific conductivity was nearly in proportion to the dissolved $\mathrm{SO}_{4}^{2-}$ amount. The decrease in the $\mathrm{pH}$ is thought to be due to formation of $\mathrm{H}^{+}$caused by the ion exchange reaction between $\mathrm{Ba}^{2+}$ and $\mathrm{H}^{+}$(H-R) represented by the reaction ( 2 ). On the other
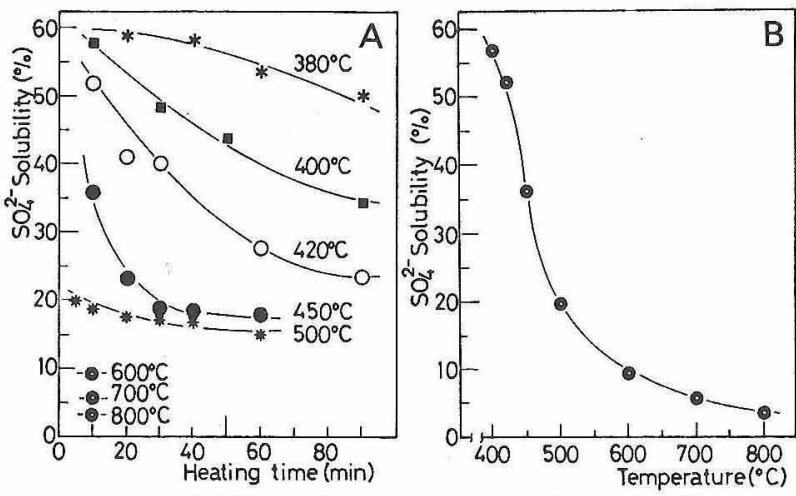

Fig. 6. solubility of $\mathrm{BaSO}_{4}$ vs, calcining condition showing the deactivation of the powder surface.

A ; Effect of heating time at each temperature.

$\mathrm{B}$; Effect of heating temprature treated for $10 \mathrm{~min}$.

hand, the amount of the dissolved $\mathrm{SO}_{4}^{2-}$ was not in proportion to that of $\mathrm{H}-\mathrm{R}$, indicating the decrease in the exchange capacity due to some kinetic factors.

Consequently, the dissolution procedure of $\mathrm{BaSO}_{4}$ in the presence of $\mathrm{H}-\mathrm{R}$ can be understood by dividing it into a few stages, namely, the dissolution of $\mathrm{BaSO}_{4}$ in $\mathrm{H}_{2} \mathrm{O}$, the migration of $\mathrm{Ba}^{2+}$ to the surface of $\mathrm{H}-\mathrm{R}$ and the ion exchange of $\mathrm{Ba}^{2+}$ for $\mathrm{H}^{+}$in $\mathrm{H}-\mathrm{R}$. As a whole, the dissolution rate exhibits considerable dependence on the dissolution condition.

\subsection{Temperature dependence of activity of} the calcined $\mathrm{BaSO}_{4}$ powders

As the solubility of the powders depends on the dissolution condition and the ion exchange reaction undergoes the reverse reaction in the concentration range above ca. $0.02 \mathrm{~N} \mathrm{H}_{2} \mathrm{SO}_{4}^{4}$, small

amounts of the $\mathrm{BaSO}_{4}$ powders was used so that the concentration of $\mathrm{H}^{+}$would not exceed the above level. The solubility of the $\mathrm{BaSO}_{4}$ powders was examined under the conditions described as follows. About $100 \mathrm{mg} \mathrm{BaSO}$ powders calcined at various temperatures were weighed accurately and put into $25 \mathrm{ml} \mathrm{H}_{2} \mathrm{O}$ together with $4.0 \mathrm{~g} \mathrm{H}-\mathrm{R}$, then stirred for $3 \mathrm{~min}$ and filtered while the residue was washed with $300 \mathrm{ml} \mathrm{H}_{2} \mathrm{O}$, followed by adjustment to $500 \mathrm{ml}$ in a volumetric flask. Subsequently, the amount of the dissolved $\mathrm{SO}_{4}^{2-}$ in the resultant solution was determined. The solubility dependence on the calcination temperature is shown in Fig. 6. Even at the temperature as low as $380^{\circ} \mathrm{C}$, the solubility gradually decreased with the period of calcination. As the temperature was raised, the solubility decreased sharply with calcination time while it again turned to decrease
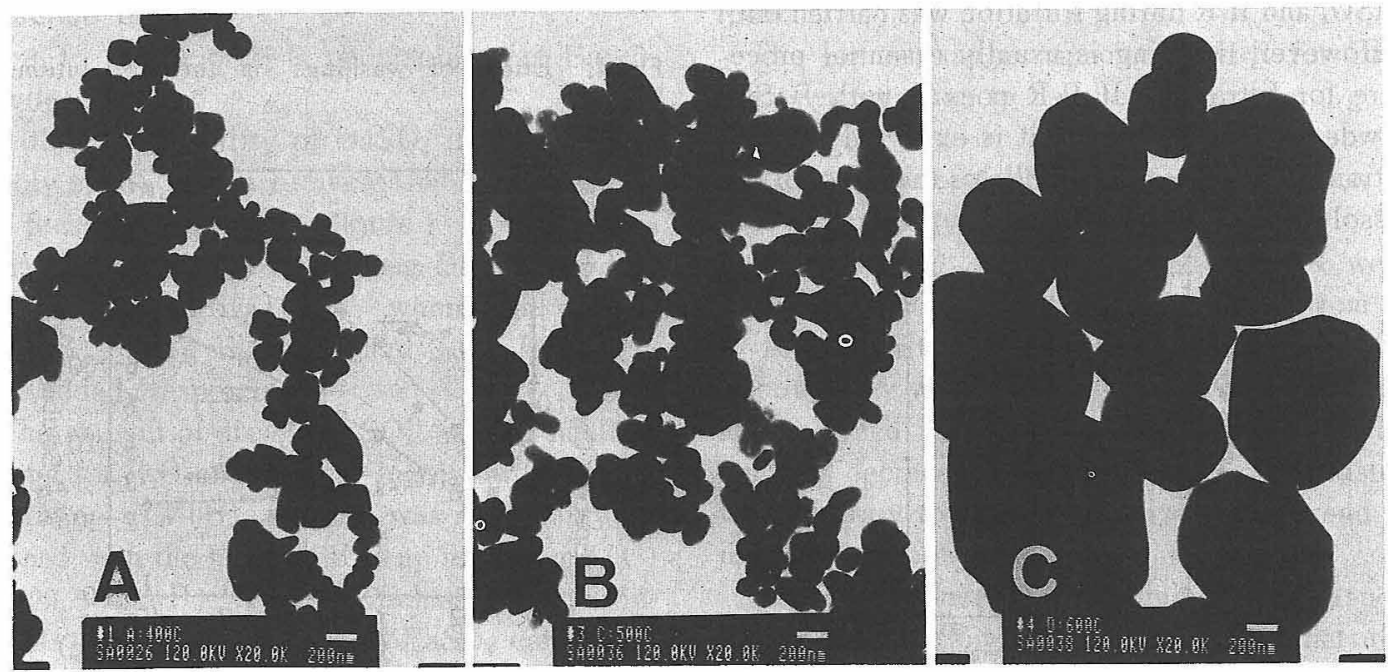

Fig. 7. TEM of $\mathrm{BaSO}_{4}$ calcined at each temperature for $10 \mathrm{~min}$.

A ; $400^{\circ} \mathrm{C}, \mathrm{B} ; 500^{\circ} \mathrm{C}, \mathrm{C} ; 600^{\circ} \mathrm{C}$ (Bar : $200 \mathrm{~nm}$ ) 


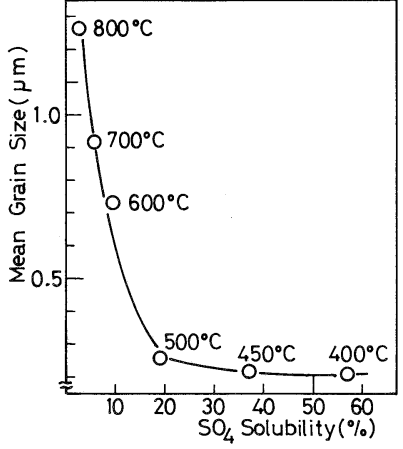

Fig. 8. Relationship between mean grain size and solubility of $\mathrm{BaSO}_{4}$ calcined at each temperature for $10 \mathrm{~min}$.

gradually in higher calcination temperature region. The change is marked in the temperature range from $400^{\circ}$ to $500^{\circ} \mathrm{C}$ having the most remarkable one around $450^{\circ} \mathrm{C}$. The TEM microphotographs corresponding to the powders calcined at $400^{\circ}, 500^{\circ}$ and $600^{\circ} \mathrm{C}$ are exhibited in Fig. 7. Significant change in size and shape can be found for the powders calcined at $500^{\circ}$ and $600^{\circ} \mathrm{C}$.

From the observation by SEM, the particles became more or less round and underwent necking partly. Those calcined at $600^{\circ} \mathrm{C}$ began to sinter and exhibited remarkable grain growth.

Comparing the change in the morphology with that in the solubility, it is found that the solubility had changed markedly before significant alternation in the particle size and shape took place. The relationship between the solubility and the mean particle size for the powders calcined at each temperature for $10 \mathrm{~min}$ is shown in Fig. 8. In the low temperature region $\left(400^{\circ}-500^{\circ} \mathrm{C}\right)$, the solubility changed sharply while the particle size changed slightly. On the contrary, in the high temperature region, the particle size changed markedly while the solubility changed a little.

Consequently, the decrease in the solubility of $\mathrm{BaSO}_{4}$ in the presence of $\mathrm{H}-\mathrm{R}$ is thought to be associated with the commencement substantial migration to the particle surface in the presintering stage.

It is not clear, at the moment, whether the solubility dominating factor is the morphology change or relaxation of the lattice imperfections introduced during the powder preparation. Although more precise data should be accumu- lated to clarify the mechanism, it is inferred that both factors would contribute to a certain extent to decrease the solubility.

As this technique is considered applicable to most of sparingly soluble solids, it would be an effective method to estimate activity or to relate the solubility with other properties regarding the solids with poor solubility.

\section{Summary and conclusion}

As to the sparingly soluble $\mathrm{BaSO}_{4}$ powders, the solubility in the presence of $\mathrm{H}-\mathrm{R}$ was determined and its temperature dependence for the powders calcined under various conditions was examined. The latter was employed as a simple indication to estimate the activity of the calcined powders.

The solubility was drastically promoted by the coexistence of $\mathrm{H}-\mathrm{R}$, the degree of which depended sensitively on the dissolution conditions owing to complexity of the dissolution mechanism.

In the low calcination temperatures, the solubility of the $\mathrm{BaSO}_{4}$ powders decreased gradually with the period of calcination, whereas it decreased sharply in the intermediate temperature region and again turned to decrease gradually with the time in the higher temperature region.

From the observation of the calcined powders in combination with the solubility data, it is inferred that the significant activity decrease in the intermediate temperature region would be caused by the change in morphology or relaxation of the lattice imperfection.

Acknowledgement The authors thank Mr. Shigeru Harada (Organo Co., Ltd.) for supplying ultra pure water and $\mathrm{Mr}$. Shoji Akahane (Matsumoto Dental College) for taking electron micrographs.

\section{References}

1) K Hamano, Ceramics Japan, 7, 231-42 (1972).

2) Y. Arai, Gypsum \& Lime, No. 198, 253-63 (1985).

3) T. Kubo, Kogyo Kagaku Zasshi, 71, 1301-09 (1968).

4) T. Nishino, T. Sakurai and Y. Moriyoshi, YogyoKyokai-Shi, 94, 267-72 (1986)

5) C. H. Bovington, J. Inorg. Nucl. Chem., 27, 1975-79 (1965).

6) R.D. Goodenough and V.A. Stenger, "Comprehensive Inorganic Chemistry", Ed. J.C. Bailar, H. J. Emeleous, Sir Ronald Nyholm and A.F. TrotmanDickenson, Vol. 1, Pergamon Press, p. 624. 